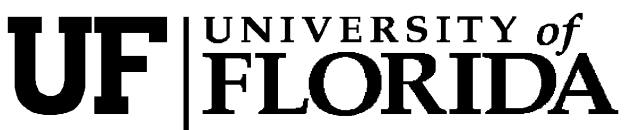 \\ IFAS Extension
}

\section{'UF-331' and 'UF-340' - Two University of Florida Dwarf Caladium Varieties for Containers and Landscapes ${ }^{1}$}

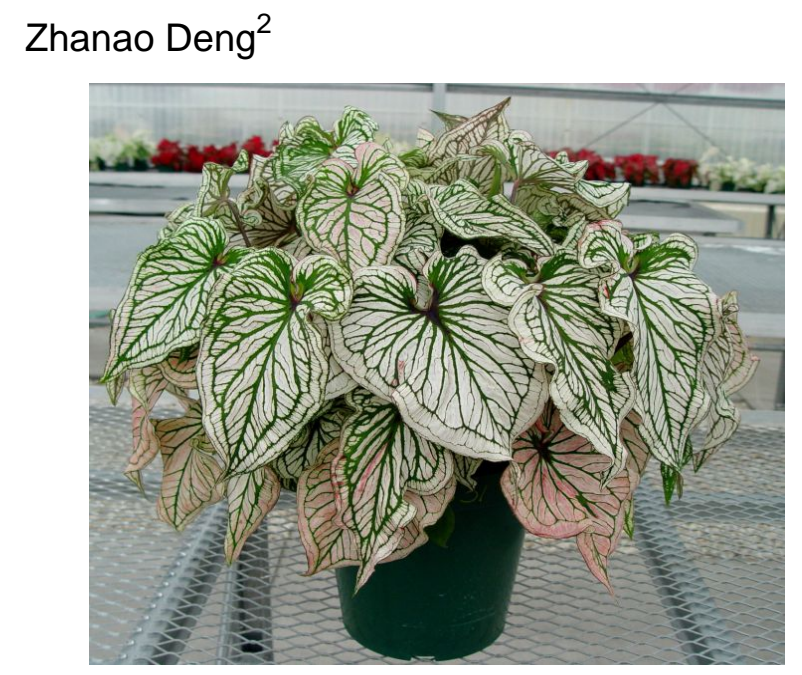

Figure 1. 'UF-331' plant produced by forcing three intact Jumbo (2 1/2 - $31 / 2$ inches in diameter) tubers in a 10-inch pot and photographed 10 weeks after planting. Credits:

Zhanao Deng (University of Florida)

'UF-331' and 'UF-340' are two new lance-leaved caladium varieties with novel combinations of foliar characteristics (Deng et al., 2008). Leaves of 'UF-331' are characterized by large, dark-green veins and white interveinal areas.

'UF-340' develops a large number of wide lance leaves with a large, bright-white center surrounded by green margins.

These varieties' performance in container forcing and landscape use is also improved in comparison to

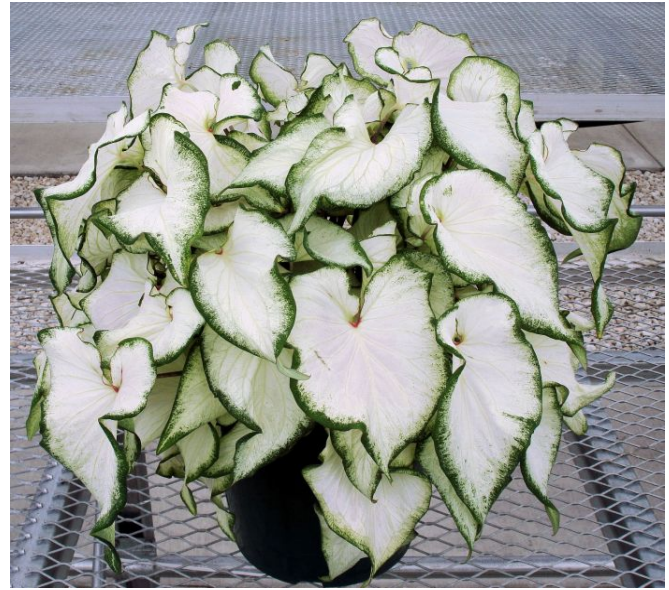

Figure 2. 'UF-340' plant produced by forcing three intact Jumbo (2 1/2 - $31 / 2$ inches in diameter) tubers in a 10-inch pot and photographed 10 weeks after planting. Credits: Zhanao Deng (University of Florida)

other white, lance-leaved varieties. In tuber yield, both of these varieties were similar to or better than the currently available, commercial white lance-leaved varieties. 'UF-331' and 'UF-404' produce multi-branched tubers that do not require de-eyeing for container forcing.

1. This document is ENH1109, one of a series of the Environmental Horticulture Department, Florida Cooperative Extension Service, Institute of Food and Agricultural Sciences, University of Florida. Original publication date, January 2009. Visit the EDIS Web site at http://edis.ifas.ufl.edu.

2. Zhanao Deng, assistant professor, Environmental Horticulture Department, Gulf Coast Research and Education Center -- Wimauma, FL, Cooperative Extension Service, Institute of Food and Agricultural Sciences, University of Florida.

The Institute of Food and Agricultural Sciences (IFAS) is an Equal Opportunity Institution authorized to provide research, educational information and other services only to individuals and institutions that function with non-discrimination with respect to race, creed, color, religion, age, disability, sex, sexual orientation, marital status, national origin, political opinions or affiliations. U.S. Department of Agriculture, Cooperative Extension Service,

University of Florida, IFAS, Florida A. \& M. University Cooperative Extension Program, and Boards of County Commissioners Cooperating. Interim Dean Millie Ferrer. 


\section{Origin}

'UF-331' and 'UF-340' were developed from a cross between 'Florida Sweetheart' and 'Florida Fantasy' and a cross between 'Florida Moonlight' and 'Florida Sweetheart', respectively. 'Florida Sweetheart' and 'Florida Fantasy' are commercial varieties produced by crossing 'Candidum Junior' and 'Red Frill'. 'Florida Moonlight' is a commercial variety selected from the cross 'Aaron' and 'Candidum Junior'. The ancestry of 'Aaron', 'Candidum Junior' and 'Red Frill' are unknown although 'Candidum Junior' is suspected to be a field mutation of 'Candidum' (Wilfret, 1991).

\section{Description}

'UF-331': Leaves are lance-shaped and have a thick central main vein in dark green and numerous large veins radiating from the central vein and in dark green (Figure 1). Interveinal areas are white or red-purple, depending on growing conditions and leaf maturity, and are often translucent, making the main veins very prominent. Plants grown in full sun in ground beds have an average height of 11.5 inches. Jumbo-size tubers (2 1/2 - 3 1/2 inches in diameter) are multi-branched and bear four to seven dominant buds.

'UF-340': Leaves are lance-shaped and have a white penniform venation. The central and main veins and the interveinal areas are white, and the margins are green (Figure 2). Plants grown for approximately four months in full sun in ground beds had an average height of 10.5 inches. Jumbo-size tubers ( 2 1/2 - 3 1/2 inches in diameter) are multi-branched and bear five to nine dominant buds.

\section{Tuber production}

'UF-331' and 'UF-340' were evaluated for tuber production at the Gulf Coast Research and Education Center in Wimauma, Fla., in 2006 and 2007. The soil was fine sand containing approximately 1 percent organic matter and having a pH of 6.2. In 2006, raised ground beds ( 32 inches wide and 8 inches high) were fumigated with a mixture of methyl bromide and chloropicrin at the rate of $175 \mathrm{LB}$ per acre and covered with white-on-black plastic mulch. Caladium seed pieces (tuber pieces) were planted in the beds with 6-inch spacing between rows and in rows. A constant water table was maintained below the beds, using the seep irrigation system. Osmocote controlled-release fertilizer (18-6-12, eight to nine months) was applied to the bed surface when shoots were emerging from the soil and the rate was $300 \mathrm{LB}$ nitrogen per acre. In 2007, the beds (28 inches wide and 8 inches high) were fumigated using the same fumigant mixture. Caladium seed pieces were planted with 10-inch between-row spacing and 6-inch in-row spacing. A drip irrigation system was used to provide water (approximately $6 \mathrm{~mm}$ per day) and fertilizer (6-2-8 soluble fertilizer, an average of approximately 1.7 LB nitrogen per acre per day and a total of $259 \mathrm{LB}$ per acre per growing season).

Thirty seed-tuber pieces were planted in each plot in April 2006 and April 2007, and tubers were harvested in Dec. 2006 and Jan. 2008, respectively. Tubers were graded by their maximum diameter: No. 2 (1 - 1 1/2 inches), No. 1 (1 1/2 - $21 / 2$ inches), Jumbo (2 1/2 - 3 1/2 inches), Mammoth (3 1/2 - 4 1/2 inches), and Super Mammoth (more than 4 1/2 inches).

A production index was calculated for each plot as follows: number of No. 2 tubers $\mathrm{x} 1+$ number of No. 1 tubers $\times 2+$ number of Jumbo tubers $\times 4+$ number of Mammoth tubers x $6+$ number of Super Mammoth tubers x 8. 'Florida White Ruffles', 'White Wing' (the two major white, lance-leaved varieties) and 'Candidum Junior' (a semi-dwarf, fancy-leaved variety that had a similar venation and coloration pattern) were included in the field trials as controls.

The average tuber weight of 'UF-331' was the same as 'White Wing', but was 40 percent or 50 percent greater than 'Florida White Ruffles' and 'Candidum Junior', respectively, in 2006 (Table 1). In 2007, the tuber weight of 'UF-331' was 1-fold to 3.8 -fold greater than that of the controls (Table 1). The production index was 18 - 166 percent higher for 'UF-331', compared to the controls in both 2006 and 2007. 'UF-331' produced a similar number of marketable tubers as 'Florida White Ruffles' and 'White Wing' in both 2006 (49 - 55 tubers) and 2007 (26 - 36 tubers). Compared to 'Candidum Junior', 'UF-331' produced a few more tubers (36 vs. 31) in 2007 and significantly more (54 vs. 39 ) in 2006 . The 
majority (more than 75 percent) of marketable tubers produced by 'UF-331' were in the No. 1, Jumbo, and Mammoth categories.

The tuber weight of 'UF-340' was lower than that of 'White Wing', but was similar to that of 'Florida White Ruffles' and 'Candidum Junior' in 2006 (Table 1). In 2007, the average tuber weight of 'UF-340' was 67 - 289 percent greater than that of the three controls. The production index of 'UF-340' was similar to that of 'Florida White Ruffles' and 'White Wing', but 22 percent greater than that of 'Candidum Junior' in 2006. In 2007, 'UF-340' was 1.2-fold to 2.8 -fold greater than the commercial controls. In both 2006 and 2007, 'UF-340' consistently produced the greatest number of marketable tubers, significantly higher than any of the controls. The majority of the tubers produced by 'UF-340' were in the No. 1, No. 2 and Jumbo categories, with few in the Mammoth size category.

\section{Container forcing and performance}

The suitability for container forcing was evaluated by forcing tubers in 4 1/2-inch containers. No. 1 tubers were planted either intact or de-eyed in a peat/vermiculite mix on 26 March 2007. The trial was conducted in a greenhouse with 45 percent light exclusion in Wimauma, Fla. Daily temperatures in the greenhouse were from $60^{\circ} \mathrm{F}$ to $84^{\circ} \mathrm{F}$ during the trial. 'Florida White Ruffles', 'White Wing', and 'Candidum Junior' were included as controls.

'UF-331' sprouted in 42 days (intact) or 44 days (de-eyed) after planting, six to nine days later than 'Florida White Ruffles', nine to 11 days later than 'White Wing', and 10 to 11 days later than 'Candidum Junior' (Table 2). When intact tubers were forced, 'UF-331' was approximately 6 inches tall, similar to the three controls. 'UF- 331' had seven to eight leaves on intact plants 10 weeks after planting, but approximately 13 leaves on de-eyed plants. Overall, leaves of 'UF-331' were similar to 'Florida White Ruffles', 'White Wing', and 'Candidum Junior' in length and width. 'UF-331' produced high-quality plants in small pots (4 1/2 inches in diameter) even without de-eyeing (Table 2).
'UF-340' sprouted 26 (intact) to 28 (de-eyed) days after planting, four to seven days earlier than the controls, regardless of tuber treatments (Table 2). 'UF-340' was similar to 'Florida White Ruffles' and 'White Wing' in height when tubers were intact or de-eyed. 'UF-340' produced a similar number of leaves as 'Florida White Ruffles' and 'Candidum Junior', but nearly twice as many leaves than all three controls when tubers were de-eyed. 'UF-340' produced high-quality plants in small pots (4 1/2 inches in diameter) even without de-eyeing (Table 2). When tubers were de-eyed, 'UF-340' plants were of even higher quality.

\section{Landscape performance}

Landscape performance was evaluated in 2006 and 2007 on the same plots used for evaluating tuber production. The overall plant performance was rated multiple times (July, August, and September) in each growing season, on a scale of 1 - 5, with 1 being very poor (few leaves and lack of vigor), and 5 being excellent (full plants, numerous leaves, and bright color display). Similarly, leaf tolerance to sunburn was also evaluated multiple times in each growing season on a scale of $1-5$, with 1 being very susceptible to sunburn and showing numerous sun-damaged areas or holes on leaves and 5 being resistant to sunburn and not showing any sun-damaged areas.

'UF-331' was taller (2 - 4 inches) and developed larger (2 - 3 inches longer and 1 - 2 inches wider) leaves than did 'Florida White Ruffles' and 'White Wing' (Table 3). 'UF-331' performed much better than 'White Wing' during the whole growing season, with much fuller plants and better color display. Compared to 'Florida White Ruffles', the performance ratings of 'UF-331' were higher, but the difference was significant only in the early season (July ratings). 'UF-331' had good tolerance to sunburn during the whole growing season and showed little leaf-tissue damage, resulting in the highest ratings.

'UF-340' was 10.6 inches tall, similar to 'White Wing' (9.4 inches tall), but taller than 'Florida White Ruffles' (7 inches, a very prostrate variety). (See Table 3). 'UF-340' was shorter than 'Candidum 
Junior', a semi-dwarf fancy-leaved variety. 'UF-340' produced the greatest number of leaves (33), exceeding both 'Florida White Ruffles' (27) and 'White Wing' (20). Leaves of 'UF-340' were similar to those of 'White Wing' in length, but longer than those of 'Florida White Ruffles' and wider than both varieties. The performance ratings of 'UF-340' were 3.9 - 4.4, higher than that of 'Florida White Ruffles' and 'White Wing'.

\section{Recommendation}

'UF-331' and UF-340' are intended for use in containers and landscapes. Their performance was outstanding both in pots and landscapes and superior to 'Florida White Ruffles', 'White Wing', and 'Candidum Junior'. De-eyeing is not required for either 'UF-331' and UF-340', but can help produce shorter potted plants with more leaves. In planning for tuber forcing, it may be necessary to plant 'UF-331' two or three weeks early since it sprouts later than most commercial varieties. 'UF-331' can do well in sunny or shady landscape locations, but 'UF-340' performs better in partially shady locations.

\section{Availability}

'UF-331' and 'UF-340' will be marketed under the trade name Angel Wing Dwarf Tricolor and Angel Wing Dwarf White. A plant patent application will be submitted to the United States Patent and Trademark Office and plant patent rights assigned to the University of Florida, Board of Trustees. Propagation and distribution will be licensed by the Florida Foundation Seed Producers, Inc., P.O. Box 110200, Gainesville, FL 32611. Information on tuber availability and propagation agreements can be obtained from the Florida Foundation Seed Producers, Inc., http://ffsp.net/.

\section{References Cited}

Deng, Z., B.K. Harbaugh, and N.A. Peres. 2008. 'UF-331' and 'UF-340' - New Dwarf Caladium Cultivars for Landscape and Pot Plants. HortScience 47(7):2231-2235.

Wilfret, G.J. 1991. Florida Sweetheart, a rose lance caladium for landscape and containers. Univ. Fla., Inst. Food Agric. Sci., Circ. S-380. Gainesville, FL. 
Table 1. Tuber weight, production index, and tuber grade distribution of caladium varieties harvested in 2006 and 2007.

Values presented are means of three replications with 30 propagules per 13.5-square-foot plot per year.

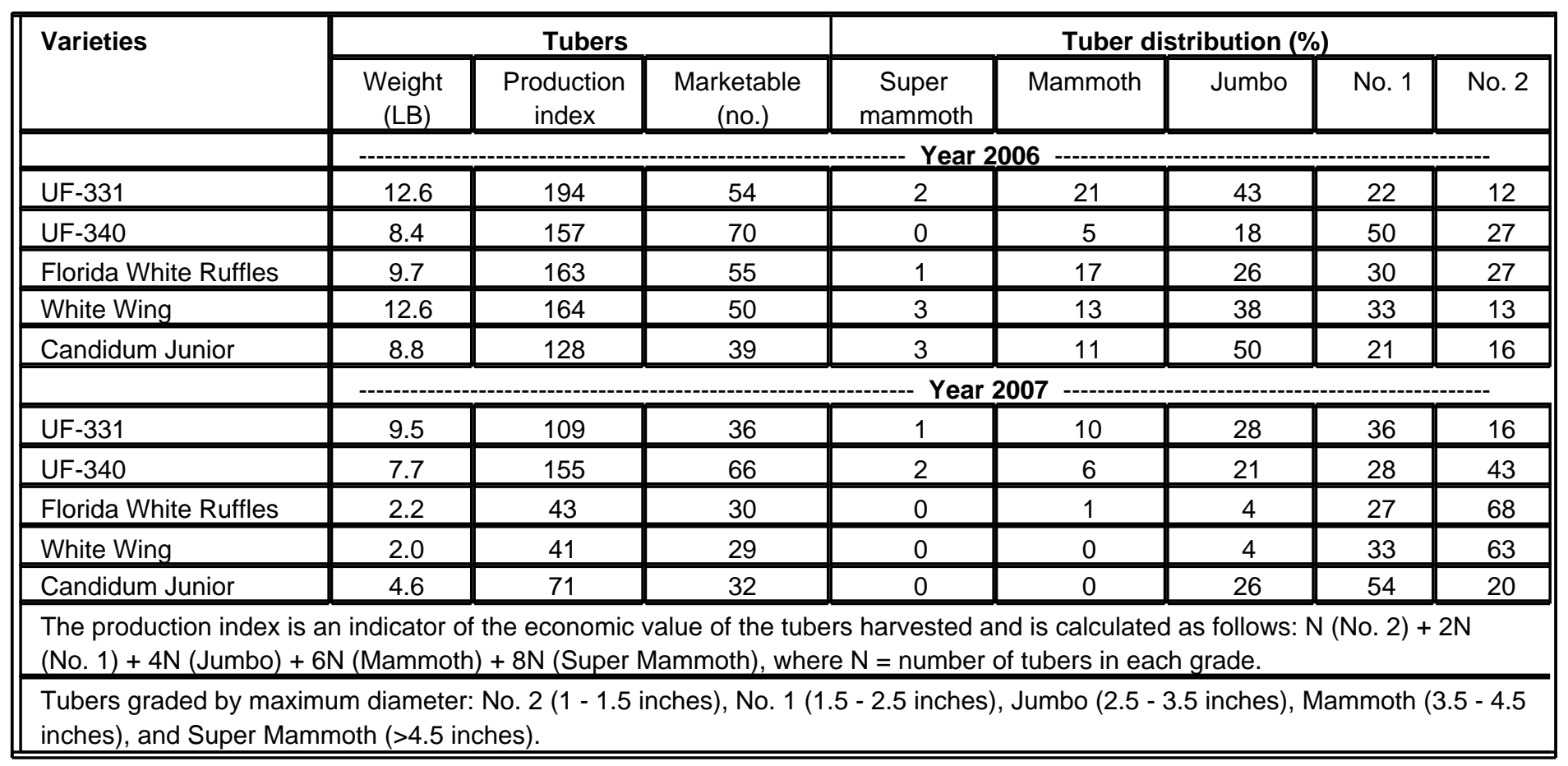




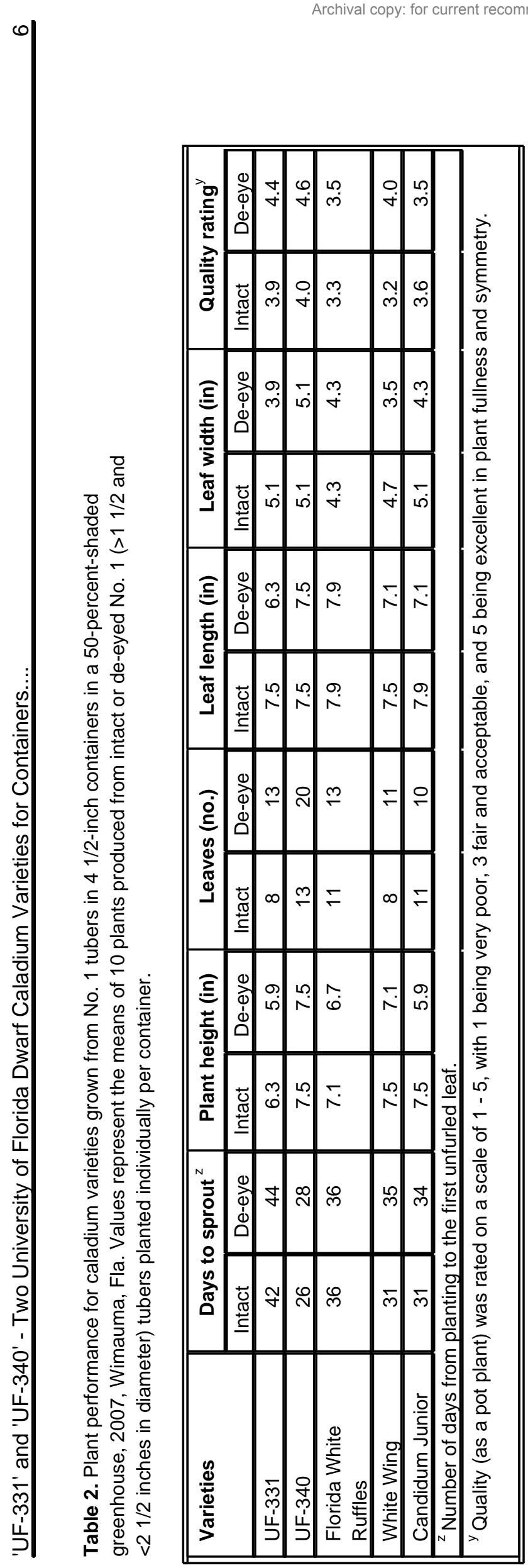




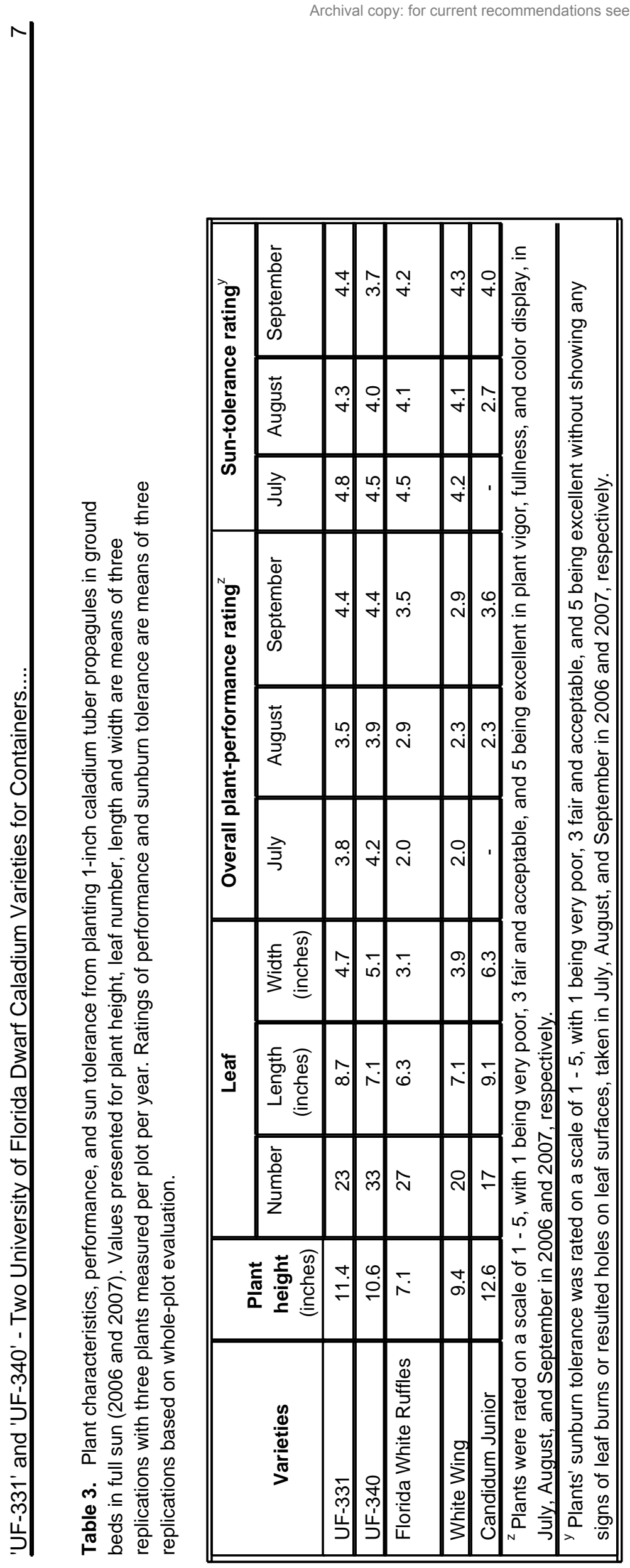

